\title{
Pengembangan Penalaran Kuantitatif di Sekolah Dasar untuk Mengembangkan Berpikir Aljabar di Sekolah Menengah Pertama
}

\author{
Dzikra Fu'adiah $^{1}$ \\ ${ }^{1}$ STAI Siliwangi Bandung, dzikra.fuadiah@gmail.com
}

\begin{abstract}
ABSTRAK
Penalaran kuantitatif merupakan suatu penalaran yang menekankan pada penarikan kesimpulan berdasarkan data-data atau informasi kuantitatif. Sedangkan berpikir aljabar dikembangkan untuk melihat dan mempresentasikan pola dan hubungan yang direpresentasikan dalam ekspresi-ekpresi aljabar.

Siswa belajar aljabar secara formal di kelas VII dan VIII. Pokok bahasan yang diberikan adalah bentuk aljabar dan sistem persamaan linier dua variabel. Kesulitan yang dialami oleh siswa adalah ketika menyelesaikan masalah kontekstual, terutama masalah yang kompleks. Sebagian besar siswa hanya menghafalkan algoritma atau metode dalam menyelesaikan masalah tanpa memahami dengan baik hubungan antara informasi-informasi yang diberikan dengan pertanyaan dalam masalah. Solusi dari masalah tersebut adalah menggunakan pendekatan pengembangan penalaran kuantitatif yang dimunculkan dalam proses pembelajaran matematika dari jenjang pendidikan dasar. Solusi tersebut dapat dilakukan karena terdapat hubungan timbal balik antara pengembangan jangka panjang kemampuan aljabar siswa dengan pengembangan jangka panjang penalaran kuantitatif siswa. Langkah selanjutnya adalah mengembangkan kegiatan pembelajaran matematika di SD yang berfokus pada mengembangkan penalaran kuantitatif siswa, karena penalaran kuantitatif dapat dikembangkan mulai dari seseorang berumur lima tahun, sehingga dapat dimulai dari siswa mengenal bilangan.
\end{abstract}

Kata Kunci: Penalaran Kuantitatif, Berpikir Aljabar.

\begin{abstract}
Quantitative Reasoning is a reasoning that emphasizes on drawing conclusion based on data or quantitative information. While, algebraic reasoning is developed to recognize and represent patterns and relationships which is represented in algebraic expressions.

Students begin to learn the formal algebra at VII and VIII grade. The topic the students learn are the system of two-variable linear equations and the algebraic form. The difficulties students experienced was to solve contextual problems, especially the complex problems. Most of students simply memorized the algorithms and methods to solve problems without a good and deep understanding
\end{abstract}


about the relationship between the given information and the question. The solution of this situation is the usage of quantitative reasoning that can be emerged in the learning activities of elementary-school students. The solution can be conducted because there is a reciprocal relation between the long-term development of algebraic abilities and the long-term development of quantitative reasoning. The next step is to develop learning activities of mathematics to elementary-school students that focuses on developing students' quantitative reasoning, because quantitative reasoning can be developed at five years. It can be started from the early class, namely when students have the class of the introduction of numbers.

\section{Keywords: Quantitative Reasoing, Algebraic Reasoning.}

\section{Pendahuluan}

Aljabar digunakan untuk memecahkan masalah sehari-hari. Dengan bahasa simbol, dari relasi-relasi yang muncul, masalah-masalah dipecahkan secara sederhana. Aljabar adalah topik inti dalam matematika dan khususnya di matematika sekolah menengah. Peran aljabar tidak hanya sebagai bahasa bagi ilmu pengetahuan alam, tetapi juga sebagai pintu gerbang ke matematika lanjutan dan pendidikan yang lebih tinggi. Pengetahuan dan kemampuan aljabar sangat relevan dalam kehidupan sehari-hari dan profesional bahkan secara langsung maupun sebagai suatu prasyarat untuk mempelajari atau melaksanakan sesuatu Katz dalam [1]). Oleh karena itu, pembelajaran aljabar di SMP adalah proses awal untuk berhasil dalam proses pembelajaran matematika secara umum.

Dalam kurikulum yang diterapkan saat ini (Kurikulum 2013) pengenalan aljabar sebagai transisi dari aritmetika di Sekolah Dasar (SD) dimulai dengan pengenalan bentuk aljabar di kelas VII dengan empat kompetensi dasar, yaitu: (1) mampu menjelaskan bentuk aljabar dan unsur-unsurnya menggunakan masalah kontekstual; (2) menjelaskan dan melakukan operasi pada bentuk aljabar (penjumlahan, pengurangan, perkalian, dan pembagian); (3) menyelesaikan masalah yang berkaitan dengan bentuk aljabar; (4) menyelesaikan masalah yang berkaitan dengan operasi pada bentuk aljabar [2]. Kurikulum 2013 berusaha untuk mengembangkan kemampuan siswa untuk menyelesaikan masalah kontekstual yang berkaitan dengan bentuk aljabar.

Pembelajaran aljabar sepatutnya mampu mempersiapkan siswa untuk mengembangkan pemahaman terhadap konsep dan keterkaitan konsep dalam matematika hingga siswa mampu memanipulasi, memformalisasikan dan merepresentasikan cara siswa berpikir tentang hubungan kuantitatif, bukan hanya melatih siswa manipulasi simbol dan menunjukkan sedikit hubungan konsep aljabar dengan dunia nyata siswa. Namun, penelitian yang dilakukan oleh Jupri menyatakan bahwa mengaplikasikan operasi aritmetika dan memahami ekspresi aljabar merupakan kesulitan-kesulitan yang dihadapi siswa SMP di Indonesia dalam mempelajari aljabar awal [1]. 
Awalnya siswa dihadapkan pada dunia bilangan dan prosedur pengoperasian bilangan (aritmetika) saat di SD dan kemudian diperkenalkan kepada dunia simbol dan prosedur pengoperasian simbol (aljabar). Dalam pembelajaran aljabar, siswa membangun dan mengembangkan kemampuan berpikir aljabar. Berpikir aljabar adalah melakukan generalisasi dari pengalaman dengan bilangan dan perhitungan, memformalisasikan ide-ide dengan penggunaan sistem simbol yang berguna, dan mengeksplorasi konsep dari pola dan fungsi [3].

Smith dan Thompson menyarankan penalaran kuantitatif sebagai akar untuk mengembangkan berpikir aljabar dimana ini tidak mudah dan tidak cepat untuk dilakukan. Siswa yang cakap menghasilkan penyelesaian dari berbagai pengalaman selama bertahun-tahun akan lebih sukses dalam aljabar karena itu membuat pengetahuan aritmetika dan aljabarnya lebih bermakna dan produktif. Pernyataan tersebut mengungkapkan penalaran kuantitatif yang menjadi dasar untuk mengembangkan kemampuan berpikir siswa untuk mempelajari aljabar [4].

Penalaran kuantitatif sudah ada pada anak usia lima tahun sampai dewasa. Ada tiga kemampuan penalaran utama: sekuensial (deduktif), induktif, dan kuantitatif [5]. Oleh karena itu, penalaran kuantitatif dapat dikembangkan saat siswa mulai mengenal bilangan yaitu sejak di bangku SD.

\section{Pembahasan}

\subsection{Penalaran Kuantitatif}

Penalaran kuantitatif diketahui merupakan suatu penalaran yang menekankan pada penarikan kesimpulan berdasarkan data-data atau informasi kuantitatif [6]. Dalam buku berjudul Paying Attention to Algebra Reasoning, kuantitatif berarti sesuatu yang melibatkan eksplorasi bagaimana kuantitas tertentu berhubungan atau berubah atau bertransformasi menjadi kuantitas lain. Kuantitas adalah kualitas sesuatu yang terbentuk dari proses pengukuran [7]. Panjang, luas, kecepatan dan volume merupakan beberapa atribut yang dapat diukur kuantitasnya [8]. Satu kuantitas dapat berhubungan dengan kuantitas lain, contohnya kecepatan adalah kuantitas yang berhubungan dengan kuantitas jarak dan waktu. Ketika siswa melibatkan penalaran kuantitatif, siswa berkerja dengan kuantitas-kuantitas dan hubungan-hubungan kuantitas tersebut [8]. Contohnya, seorang siswa mungkin membandingkan kuantitas-kuantitas secara aditif, dengan membandingkan seberapa lebih tinggi seseorang dengan orang lain, atau secara multiplikatif, dengan menentukan berapa kali lebih besar satu objek terhadap objek lain [8]. Informasi yang memuat informasi berupa kuantitas dan hubungan satu kuantitas dengan kuantitats lain disebut sebagai informasi kuantitatif.

Sedangkan, menurut Keraf, penalaran merupakan proses berpikir yang berusaha menghubung-hubungkan fakta-fakta atau evidensi-evidensi yang diketahui menuju kepada suatu kesimpulan [9]. Menurut NCTM penalaran kuantitatif adalah kemampuan yang dikembangkan untuk menganalisis informasi kuantitatif dan dapat menentukan kemampuan dan prosedur apa digunakan untuk menyelesaikan suatu permasalahan tertentu untuk sampai pada sebuah solusi [10]. 
Istilah penalaran kuantitatif kadang juga disebut sebagai literasi bilangan atau kuantitas atau penalaran bilangan. Menurut Davidson dan McKinney, penalaran kuantitatif dianggap bersinonim dengan istilah matematika dan keduanya saling berkaitan erat. Namun, keduanya merupakan dua hal yang berbeda, matematika merupakan suatu disiplin ilmu, sedangkan penalaran kuantitatif merupakan suatu kemampuan aplikatif praktis. Seorang matematikawan sangat menikmati hal-hal yang abstrak, namun siswa dapat menerapkan kemampuan penalaran kuantitatif dalam konteks sehari-hari. Contohnya, memahami perhitungan untung, laba; atau penggunaan dan penyalahgunaan suatu persentase; atau penerapan prinsip-prinsip logika masalahmasalah sehari-hari [11].

Dalam penalaran kuantitatif, fokus tidak boleh pada keterampilan komputasi, tapi lebih mengutamakan:

a. kemampuan untuk memilih dan menggunakan strategi komputasi yang tepat dan efisien untuk memecahkan masalah dan

b. kemampuan untuk menentukan tingkat akurasi perhitungan yang diperlukan atau kesesuaian menggunakan estimasi [10].

Siswa seharusnya tidak hanya menunjukkan perhitungan bilangan-bilangan dengan tangan, tetapi siswa harus menginterpretasikan dan menentukan keakuratan perhitungan tersebut. Sedikit siswa yang terlatih dalam mengerjakan matematika yang membutuhkan pengetahuan matematika yang kompleks, namun semua siswa seharusnya mampu memahami matematika dengan cukup baik untuk mengembangkan opini yang diberikan yang berkaitan dengan konsep kuantitatif [11].

Deskripsi tersebut yang berkaitan dengan bilangan dan kemampuan merupakan interpreasi pertama terhadap penalaran kuantitatif membuat penggunaan kemampuan matematis dapat dilakukan oleh setiap orang dengan adanya kebutuhan terhadap matematika praktis bagi kehidupan sehari-hari. Kedua, penalaran kuantitatif adalah suatu kemampuan untuk mengenal dan memahami informasi matematis, seperti grafik, bagan atau tabel atau dengan referensi persentase kenaikan atau penurunan suatu peristiwa. Deskripsi kedua menunjukkan bahwa siswa diharapkan mampu mengenal dan memahami beberapa representasi matematis yang dapat digunakan untuk mengkomunikasikan informasi tertentu [11].

\subsection{Penalaran Kuantitatif dan Berpikir Aljabar}

Aljabar secara formal diajarkan kepada siswa ketika di kelas VII SMP. Jika penalaran kuantitatif telah dikembangkan sebelum siswa memasuki proses pembelajaran aljabar awal tersebut, maka proses pengembangan berpikir aljabar awal akan lebih baik. Ketika siswa mengembangkan kemampuan berpikir aljabar, tampak siswa yang memiliki kemampuan penalaran kuantitatif yang lebih baik dalam menyelesaikan soal cerita menunjukkan perkembangan berpikir aljabar lebih baik juga [12]. Masalah yang diberikan secara lisan atau tulisan dapat siswa selesaikan dengan penalaran kuantitatif berdasarkan pengetahuan mereka sebelumnya tanpa harus khawatir menghafal bagaimana cara untuk memanipulasi simbol-simbol [12]. 
Berpikir aljabar dikembangkan untuk melihat dan mempresentasikan pola dan hubungan yang direpresentasikan dalam ekspresi-ekpresi aljabar [13]. Sedangkan, penalaran kuantitatif adalah proses untuk melihat hubungan satu atau lebih kuantitas numerik [4]. Sehingga, kedua jenis penalaran tersebut sama-sama membutuhkan kemampuan melihat suatu hubungan, penalaran dalam aljabar direpresentasikan dalam ekspresi aljabar dan penalaran kuantitatif dalam satu atau lebih kuantitas numerik.

Berikut, illustrasi perbandingan antara solusi dengan berpikir aljabar yang memanipulasi simbol-simbol dan solusi dengan penalaran kuantitatif yang lebih langsung melibatkan jumlah dan hubungan dalam suatu situasi masalah. Masalah 1 tersebut sebagai berikut:

Masalah 1 Aku berjalan dari rumah ke sekolah selama 30 menit, sedangkan adikku 40 menit. Adikku meninggalkan rumah 6 menit sebelum aku. Dalam berapa menit aku akan mengejarnya? (Krutetski [4]).

Solusi aljabar untuk masalah ini biasanya melibatkan penetapan variabelvariabel, menulis ekspresi aljabar, dan akhirnya menyatakan dan memecahkan persamaan. Jika $t$ mewakili jumlah menit aku telah berjalan, maka setiap kali aku berjalan $t$ menit adikku akan berjalan $t+6$ menit. Jika $\mathrm{d}$ variabel untuk jumlah meter jarak dari rumah ke sekolah dan jika aku dan adikku berjalan pada kecepatan konstan, maka kecepatan aku berjalan adalah $\frac{d}{30}$ meter per menit dan adikku $\frac{d}{40}$ meter per menit. Menggunakan rumus umum bahwa "kecepatan dikalikan dengan waktu sama dengan jarak" ( $d=s \times t)$, ekspresi ini dapat dinyatakan dalam persamaan, $(t+6) \frac{d}{40}=t \frac{d}{30}$, dan kemudian dapat dengan mudah diketahui solusi masalah dari bentuk setara, $\frac{t+6}{40}=\frac{t}{30}[4]$.

Masalah tersebut umumnya diselesaikan di topik aljabar karena metode aljabar dianggap dibutuhkan untuk menyelesaikannya. Pendekatan aljabar ini membuat beberapa kesimpulan eksplisit bagaimana hubungan antara kecepatan, waktu dan jarak yang terkait dalam situasi tersebut. Tapi masalah ini juga dapat diselesaikan dengan penalaran tentang hubungan antara jarak, kecepatan berjalan, dan waktu perjalanan tanpa menggunakan penyimbolan variabel atau ekspresi aljabar. Berikut adalah salah satu contoh dari pendekatan ini, yang disebut penalaran kuantitatif.

1. Aku membayangkan diriku berjalan di belakang adikku, melihat dia di depanku. Hal yang terpenting saat mengejar adikku adalah jarak antara kami dan berapa lama waktu yang dibutuhkan untuk jarak menjadi nol.

2. Jarak antara kami menyusut pada kecepatan karena perbedaan kecepatan kami berjalan.

3. Aku membutuhkan $\frac{3}{4}$ waktu adikku berjalan ke sekolah, jadi aku berjalan $4 / 3$ kecepatan saudara.

4. Karena saya berjalan $\frac{4}{3}$ kecepatan adikku, jarak antara kita menyusut dengan kecepatan $\frac{1}{3}$ kecepatan adikku.

5. Waktu yang diperlukan untuk menempuh jarak antara kami nol ketika waktunya menjadi 3 kali waktu adikku berjalan dari tempat pertama (6 menit).

6. Oleh karena itu, aku akan menyusul adikku dalam 18 menit. (Krutetski dalam [4]). 
Seperti solusi aljabar, penalaran kuantitatif ini membutuhkan pemahaman yang kaya tentang berapa waktu, kecepatan, dan jarak berhubungan, bagaimana hubungan tersebut dapat digunakan untuk menarik kesimpulan, dan bagaimana nilai-nilai numerik dapat disimpulkan dari yang diketahui. Dua solusi berbeda sangat jelas dalam penggunaan simbol-simbol aljabar. Namun lebih berbeda lagi, pada penyelesaian pertama fokus pada menerjemahkan hubungan menjadi simbol dan yang kedua fokus pada mengekspresikan dan bekerja secara langsung dengan hubungan tersebut.

Berpikir aljabar ditandai dengan keumumannya dan peran ekspresi simbolik yang bermain dalam menyatakan hubungan umum, perbandingan dan pemanipulasian masalah, dan memfasilitasi berbagai evaluasi numerik. Ketika penalaran kuantitatif dikembangkan kepada siswa, mereka mengembangkan ide-ide matematis dan akhirnya akan menemukan kesadaran untuk mengungkapkan dalam notasi aljabar. Sederhananya, penalaran kuantitatif menyediakan konten konseptual untuk siswa membentuk representasi yang kuat dalam aljabar dan memanipulasinya [4].

Penelitian yang menkaji bagaimana konsep dan representasi aljabar diperkenalkan dan dikembangkan di sekolah dasar menyimpulkan bahwa tujuan utama pembelajaran konsep aljabar awal untuk memperdalam pemahaman siswa terhadap hubungan kuantitatif [14]. Sehingga, terhadapat hubungan yang saling menguntungkan untuk mengembangkan kedua penalaran. Penalaran kuantitatif anak mempermudah siswa dalam mengembangkan berpikir aljabar.

\subsection{Transisi dari Penalaran Aritmetika ke Berpikir Aljabar Siswa SMP dengan Penalaran Kuantitatif}

Dalam mendukung perkembangan kemampuan berpikir aljabar, penting untuk mengetahui arti dari kuantitas dan hubungan antara kuantitas tersebut. Perbedaan antara penalaran kuantitatif dengan berpikir aljabar pada masalah 1 ditekankan pada penalaran prosedur simbolik terhadap kuantitas-kuantitas dan hubungan kuantitas-kuantitas tersebut. Berikutnya, perbedaan akan ditekankan antara penalaran terhadap bilangan dan perhitungannya dan penalaran terhadap kuantitas dalam suatu situasi masalah yang biasanya tampak seperti masalah aritmetika.

Masalah 2 Pada suatu waktu di masa yang akan datang John akan berusia 38 tahun. Pasaan itu John akan tiga kali lebih tua daripada putrinya Sally. Sally saat ini berusia 7 tahun. Berapa usia John sekarang? (diadaptasi dari [4])

Untuk solusi numerikal/perhitungan, masalah 2 adalah masalah aritmetika yang dapat diselesaikan dengan tiga langkah. Untuk menyelesaikan masalah 2, siswa harus terlebih dahulu membagi 38 dengan 3 untuk menentukan usia Sally di masa yang akan datang, yaitu $12 \frac{2}{3}$ tahun; kemudian $12 \frac{2}{3}$ dikurangi oleh 7 untuk menentukan perbedaan antara usia Sally di "masa yang akan datang” dengan "sekarang', yaitu $5 \frac{2}{3}$ tahun; dan terakhir, mengurangi $5 \frac{2}{3}$ dari 38 untuk menentukan usia John sekarang, yaitu $32 \frac{1}{3}$ tahun. Kebanyakan siswa SMP mengetahui bahwa tiga bilangan (38, 3 dan 7) yang akan digunakan dan memilih di antara empat operasi bilangan (penjumlahan, pengurangan, perkalian, pembagian) dalam menyelesaikan masalah 2. Siswa mengetahui harus 
menemukan urutan operasi dari pasangan bilangan mana yang benar untuk menghasilkan jawaban akhir yang benar. Dari sudut pandang ini, diskusi di kelas biasanya berpusat pada bilangan dan operasi mana dan urutan pengerjaannya bagaimana. Meskipun perhatian mungkin diberikan pada menentukan operasi (misalnya, mencatat bahwa "tiga kali lebih tua" adalah petunjuk untuk melakukan operasi perkalian), sehingga fokus utama pada solusi penalaran aritmetika pada bilangan dan perhitungannya [4].

Sedangkan solusi kuantitatif/konseptual, diilustrasikan dengan mengidentifikasi kuantitas-kuantitas apa saja dalam masalah 2, yaitu "usia John di masa yang akan datang", "usia Sally di masa yang akan datang", "usia Sally sekarang", dan "usia John sekarang". Usia-usia tersebut dan beberapa hubungan diantara usia-usia tersebut dianalisis (seperti satu orang lebih tua, usia-usia mereka berubah dengan perubahan yang sama) tanpa mengetahui nilai numerik dari usia-usia tersebut. Fakta bahwa mengetahui nilai-nilai dari kedua usia (yaitu usia John di masa yang akan datang 38 tahun dan usia Sally sekatang 7 tahun) merupakan hal yang tidak penting dalam kemampuan menganalisis perubahan usia tersebut dari waktu ke waktu. Keempat kuantitas tersebut tidak mewakili "apa yang terjadi” dalam masalah 2. Untuk memahami secara penuh, perlu untuk mengenali tiga hubungan penting yang mengintegrasikan empat kuantitas tersebut menjadi struktur yang jelas dan masuk akal [4].

a. Terdapat hubungan sementara bahwa waktu "bergerak" dari "waktu sekarang" ke "waktu kemudian" yang menghubungkan usia John dan usia Sally. (Gambar 1)

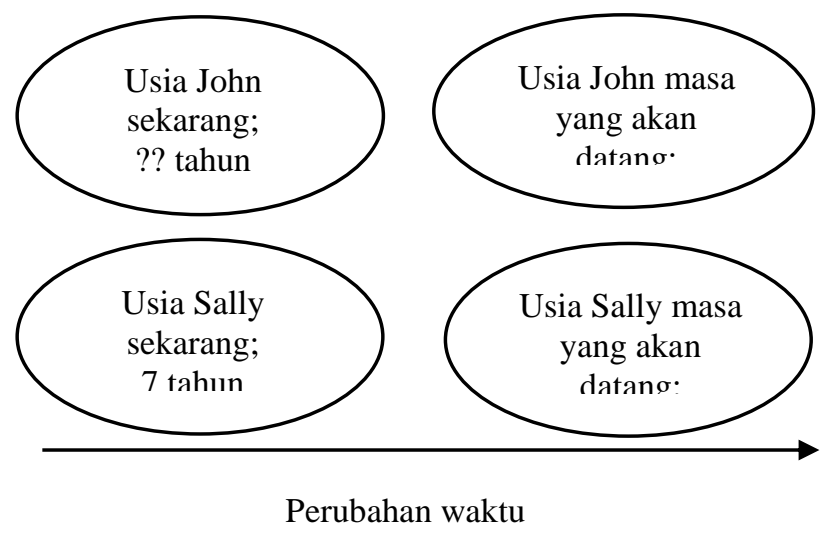

Gambar 1 Usia keduanya ketika waktu berubah

b. Sally semakin tua, John (dan setiap orang) akan semakin tua juga dengan penambahan usia yang sama, sehingga perbedaan usia Sally sekarang dan usianya di masa yang akan datang akan sama dengan perbedaan usia John sekarang dengan usianya di masa yang akan datang. 


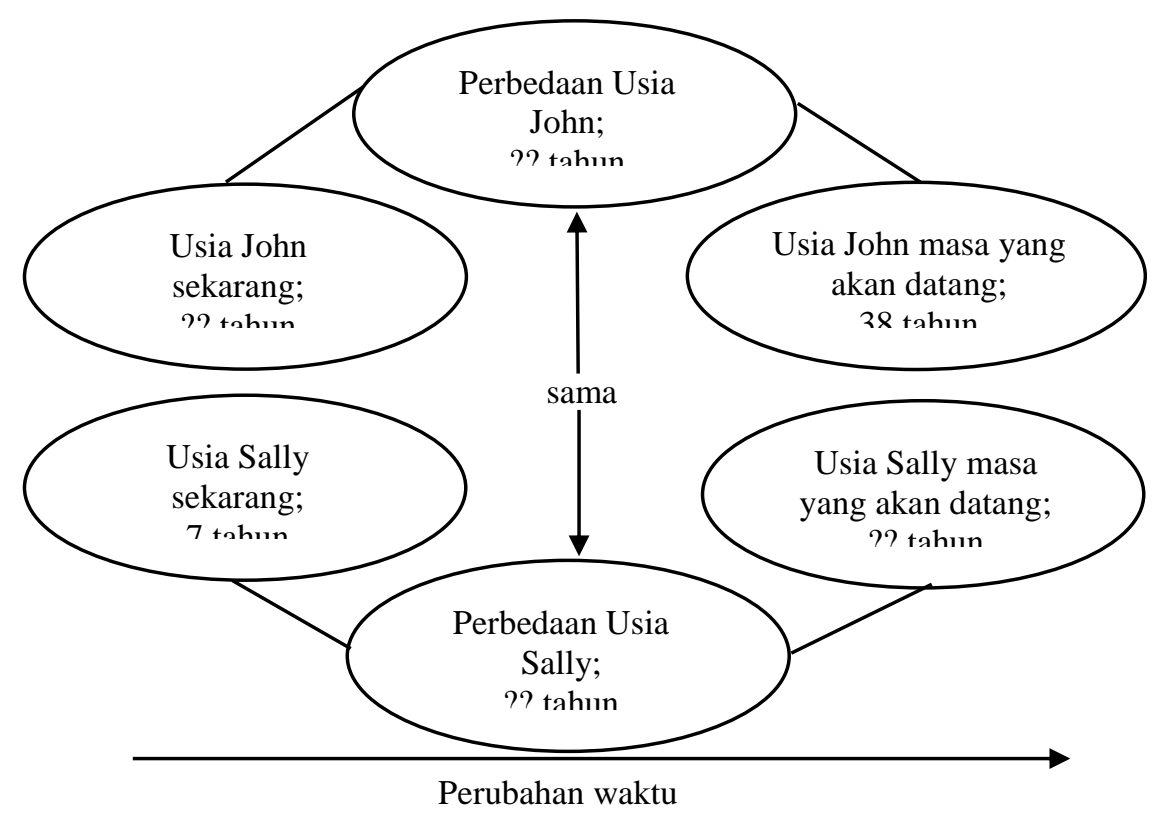

Gambar 2 Berapa lama waktu yang berlalu sama bagi setiap orang

c. Hubungan ketiga menyediakan hubungan yang penting antara usia John dan usia Sally. Pada titik tertentu di masa yang akan datang, usia John akan tiga kali lebih tua daripada usia Sally. Hubungan tersebut biasanya disebut rasio. Besar rasio ini menggambarkan berapa kali lebih besar ukuran satu kuantitas dengan kuantitas lain sebagai ukuran bagi kuantitas lain tersebut.

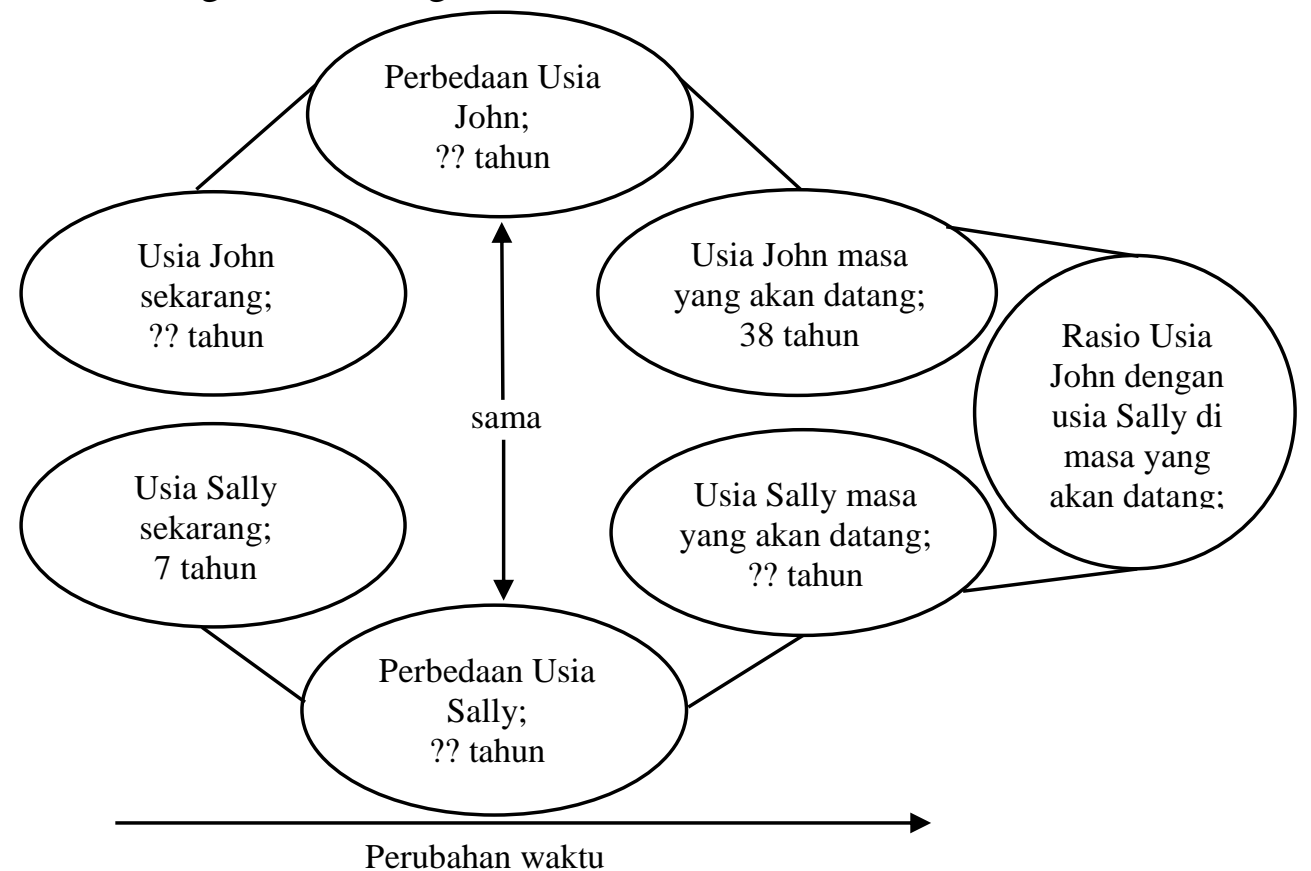

Gambar 3 Hubungan antara kuantitas-kuantitas

Illustrasi tersebut (Gambar 3) memudahkan dalam memutuskan perhitungan apa yang dibutuhkan. Ketika usia John di masa yang akan datang adalah tiga kali lebih tua 
daripada usia Sally di masa yang akan datang, usia Sally pada waktu itu akan $\frac{1}{3}$ usia John. Oleh karena itu, ini masuk akal jika membagi usia John di masa yang akan datang dengan 3 untuk mementukan usia Sally di masa yang akan datang juga. Usia Sally sekarang dan akan datang diketahui, sehingga pertambahan usia Sally dapat ditentukan, yaitu $\frac{38}{3}-7$, atau $\frac{17}{3}$ tahun. Karena pertambahan usia John dan Sally sama (yaitu $\frac{17}{3}$ ), maka $\frac{17}{3}$ tahun berikutnya John akan berusia 38 tahun. Sehingga perhitungan akhir mencari umur John sekarang dapat dilakukan, yaitu $32 \frac{1}{3}$ tahun [4].

Tujuan menunjukkan contoh masalah ini adalah untuk menekankan kekayaan penalaran matematis akan dimiliki jika berfokus pada kuantitas-kuantitas dan hubungan antara kuantitas-kuantitas tersebut. Daripada hanya berfokus pada bilangan dan operasi aritmetik. Ketika siswa tidak memperhatikan kuantitas dan hubungannya, pemecahan masalah siswa dengan cepat menjadi bahan perdebatan yang tidak berdasar tentang pemilihan bilangan-bilangan pada masalah dan operasi-operasi yang akan digunakan untuk menyelesaikan masalah [15].

\subsection{Pembelajaran Aljabar}

Salah satu aspek belajar aljabar di SMP adalah belajar tentang operasi bilangan dan sifat-sifatnya beserta relasi antar bilangan-bilangan tersebut dalam bahasa simbol yang berupa angka, huruf, atau notasi lainnya [16]. Komunikasi dengan simbol merupakan suatu bentuk bahasa. Karena itu belajar aljabar dapat dipandang sebagai belajar bahasa simbol dan relasi antar bilangan. Jadi, perlu dipahami konsep dan kesepakatan-kesepakatan dasar yang digunakan dalam bahasa matematika, yaitu aljabar.

Saat ini, pendekatan yang terbaik untuk menyelesaikan masalah matematika yang kompleks adalah dengan menggunakan aljabar sebagai alat untuk membantu mengatasi kompleksitas tersebut. Seseorang bisa berpindah dengan cepat dari situasi masalah yang memiliki hubungan-hubungan yang kompleks ke ekspresi-ekspresi aljabar dan numerik dan manipulasi-manipulasinya [4].

Siswa belajar aljabar lebih lanjut di kelas VIII. Pokok bahasan yang diberikan kepada siswa kelas VIII adalah sistem persamaan linier dua variabel. Kesulitan yang dialami oleh siswa adalah ketika menyelesaikan masalah kontekstual, terutama masalah yang kompleks [1]. Sebagian besar siswa hanya menghafalkan algoritma atau metode dalam menyelesaikan masalah tanpa memahami dengan baik hubungan antara informasi-informasi yang diberikan dengan pertanyaan dalam masalah. Solusi dari masalah tersebut adalah menggunakan pendekatan lain yaitu melalui penalaran kuantitatif yang dimunculkan dalam proses pembelajaran matematika dari jenjang pendidikan dasar. Karena terdapat hubungan timbal balik antara pengembangan jangka panjang kemampuan aljabar siswa dengan pengembangan jangka panjang penalaran kuantitatif siswa [17]. Oleh karena itu, penalaran kuantitatif seharusnya dibangun dari kegiatan belajar matematika awal siswa, yaitu sejak siswa di SD.

Ada dua pandangan dalam memperkenalkan aljabar: (1) program saat ini, penekanan pada ekspresi numerik dan simbolik dan manipulasinya yang pada dasarnya 
tidak baik; dan (2) program yang diusulkan, menggunakan pendekatan awal yaitu penalaran kuantitatif [4]. Skema berikut mengillustrasikan kedua pandangan tersebut.

Program saat ini

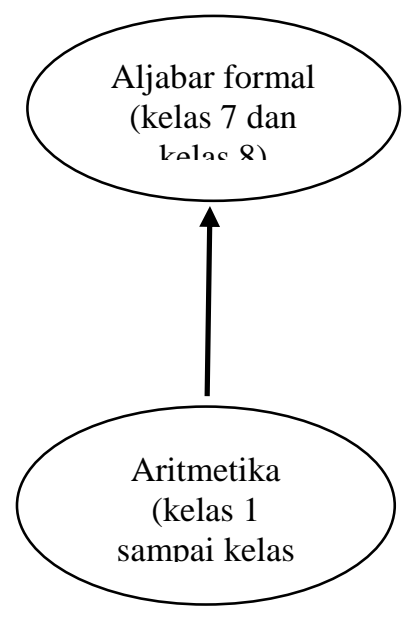

Program yang diusulkan

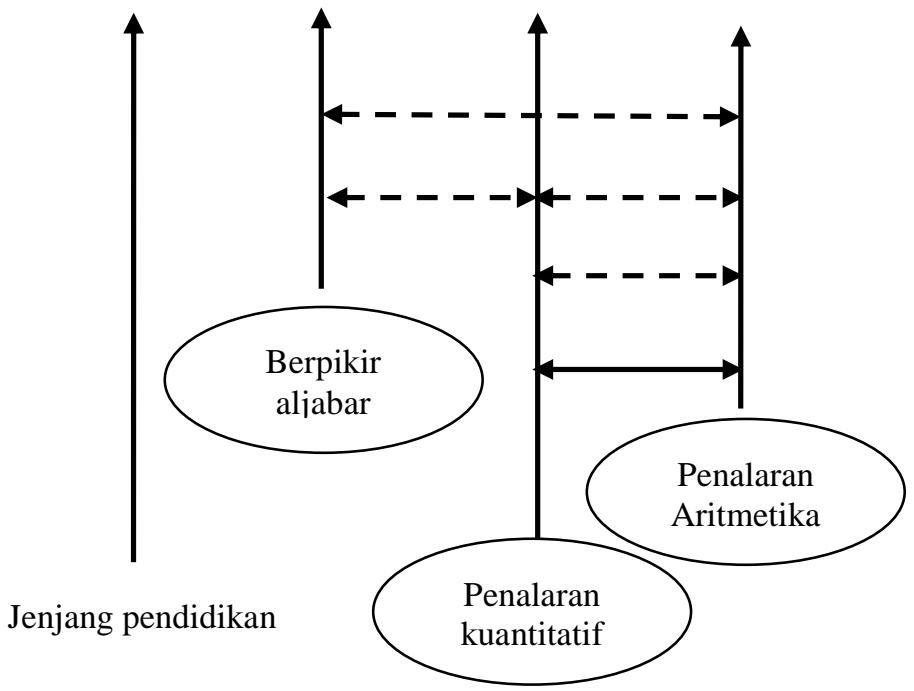

Gambar 4 Skema dua pandangan dalam memperkenalkan aljabar

\section{Kesimpulan}

Pendekatan lain dapat digunakan untuk mengembangkan kemampuan berpikir aljabar siswa SMP, yaitu mengembangkan penalaran kuantitatif dalam pembelajaran matematika sejak siswa berada di jenjang pendidikan SD yang saat ini berfokus pada aritmetika (bilangan dan operasi bilangan). Pengembangan penalaran kuantitatif dapat mendukung perkembangan berpikir aljabar siswa.

Langkah selanjutnya adalah mengembangkan kegiatan pembelajaran matematika di SD yang berfokus pada mengembangkan penalaran kuantitatif siswa. Karena penalaran kuantitatif sudah ada pada anak usia lima tahun sampai dewasa [5], maka berdasarkan pendapat tersebut, penalaran kuantitatif dapat dikembangkan saat siswa mulai mengenal bilangan.

\section{DaftarPustaka}

[1] Jupri, A., Drijvers, P. dan vanden Heuvel-Panhuizen, M. 2013. Difficulties in initial algebra learning in Indonesia. Dalam Mathematics Education Research Group of Australasia, Inc.

[2] As'ari, A.R., dkk. 2016. Matematika - Studi dan Pengajaran Jilis la. Jakarta: Balitbang, Kemdikbud.

[3] Walle, J.A.V. 2006. Matematika Sekolah Dasar dan Menengah Jilid 2 Edisi Keenam. Jakarta: Penerbit Erlangga.

[4] Smith, J. dan Thompson, P. W. 2007. Quantitative reasoning and the development of algebraic reasoning. Dalam J. J. Kaput, D. W. Carraher \& M. L. Blanton (Eds.), Algebra in the early grades (h.95-132). New York: Erlbaum. 
[5] Carroll, J.B. 1993. Human cognitive abilities: A survey of factor-analytic studies. Cambridge, England: Cambridge University Press.

[6] Sroyer, A. 2013. Penalaran Kuantitatif (Quantitatatif Reasoning) dalam Pemecahan Masalah Matematika. Makalah disajikan pada Seminar Nasional Matematika dan Pendidikan Matematika, Yogyakarta, tanggal 9 November 2013.

[7] Thompson, P.W. 1990. A Theoretical Model of Quantity-Based Reasoning in Arithmetic and Algebra. Makalah disajikan pada the Annual Meeting of the American Educational Research Association, San Fransisco, tanggal 27-31 Maret 1989.

[8] Ellis, A.B. 2011. Algebra in The Middle Schools: Developing Functional Relationship Through Quantitative Reasoning.Madison, USA: School of Education, University of Wisconsin-Madison.

[9] Shadiq, F. 2004. Penalaran, Pemecahan Masalah dan Komunikasi dalam Pembelajaran Matematika. Yogyakarta: Depdiknas Dirjen Pendidikan Dasar dan Menengah Pusat Pengembangan Penataran Guru (PPPG) Matematika.

[10] Dwyer, C.A., Gallagher, A., Levin, J. dan Morley, M.E. 2003. What is Quantitative Reasoning? Defining the Construct for Assessment Purpose. Princeton: ETS.

[11] Davidson, M dan McKinney, G. tanpa tahun. Quantitative Reasoning: An Overview. USA: Office of Institutional Assessment and Testing, Western Washington University.

[12] Ontario Ministry of Education. 2013. Paying Attention to Algebraic Reasoning. Toronto, ON : Queen's Printer for Ontario.

[13] Mulligan, J., Cavanagh, M., dan Keanan-Brown, D. (2012). The Role of Algebra and Early Algebraic Reasoning in the Australian Curriculum: Mathematics.

[14] Cai, J., \& Lester, F. K. (2005). Solution representations and pedagogical representations in Chinese and U. S. classrooms. Journal of Mathematical Behavior, 24, 221-237.

[15] Sowder, L., dkk. 1998. Students' proof schemes. Research on Collegiate Mathematics Education, Vol. III. Dalam E. Dubinsky, A. Schoenfeld, \& J. Kaput (Eds.), AMS, 234-283.

[16] Krismanto, A1. 2009. Kapita Selekta Pembelajaran Aljabar di Kelas VII SMP. Depdiknas Dirjen Peningkatan Mutu Pendidikan dan Tenaga Kependidikan: Yogyakarta.

[17] Thompson, P.W. 2011. Quantitative Reasoning and Mathematical Modelling. Arizona State University. 